\title{
A Ductile Tear Fracture Analysis of Lap Welded Joints
}

\author{
A. Imad, ${ }^{a}$ M. Nait Abdelaziz, ${ }^{b}$ and G. Mesmacque ${ }^{b}$ \\ ${ }^{a}$ Laboratoire d'Etudes des Structures, Ecole HEI, Lille, France \\ ${ }^{\mathrm{b}}$ Laboratoire de Mécanique de Lille, Lille, France
}

удК 539.4

\section{Анализ вязкого сдвига в сварных соединениях внахлестку}

\author{
А. Имада", М. Наит Аб̆делази ${ }^{\sigma}$, Г. Месмакю ${ }^{6}$ \\ а Лаборатория исследований структуры, Лилль, Франция \\ б Лаборатория механики, Лилль, Франция
}

Выполнен численный расчет параметров вязкого разрущения колпактньх образиов, моделируюиих сварное соединение внахлестку. Исследовались моно-, би- и триметаллические конфигурации компактных образиов с иелью сравнения глобальньх (J-интеграл и раскрьтие вериинь трецинь) и локального (модель Райса-Трейси) подходов. Показано, что такие изменения конфигурации образиов не влияют на глобальные параметры, в то время как локальный параметр - коэффициент роста пор $R / R_{0}$ - весьла чувствителен к изменению полей напряжений и деформаций в окрестности вериины треиины. Предлагается направление распространения трещины в случае сварного соединения внахлестку прогнозировать nо распределению параметра $R / R_{0}$ в окрестности вериины трецинь.

Ключевые слова: вязкий сдвиг, сварные соединения внахлестку, J-интеграл, коэффициент роста пор.

Introduction. Fracture criteria based upon the global approaches are commonly applied to the ductile tearing of welded joints. For instance, the energy rate interpretation of the $J$-integral [1] allows one to assess the fracture toughness (given in terms of a critical value of this parameter) for such components. Numerous data on the influence of mismatching on fracture parameters such as $J$-integral, crack tip opening displacement (CTOD), or Charpy V-energy results are available in the literature [2-12].

As to the failure of components with mismatched strength values, most studies to be found in the literature deal with standard notched specimens (CT, SENB, SENT, etc.) exhibiting a central zone of weld metal (WM) surrounded by two adjacent zones of base metal (BM). Such specimens exhibit the fracture toughness values which do not characterize the central zone in an intrinsic manner. In fact, it is an apparent toughness which depends mainly on several parameters such as [2-5]:

- mismatch ratio;

- hardening exponents of each material (BM, WM, and HAZ);

- fracture resistance of each material; 
- size and position of the initial notch;

- length of the central zone;

- joint configuration, etc.

The mechanical heterogeneity of a welded structure (BM, WM, and HAZ) added to the heterogeneity of the microstructure (coarse-grain and fine-grain HAZ) make fracture study of such components so complicated, that a question on the validity of a global approach arises.

As ductile tearing proceeds from mechanisms essentially described by the void growth phase at the crack tip, local approaches can be applied as alternative and complementary research tools. Many theoretical models have been developed to predict the void growth rate, as well as numerical methods used for their refinement and numerical application [14-19].

In this work, a FEM analysis has been performed in order to compare these two different approaches namely the $J$-integral and CTOD parameters with the void growth rate parameter $R / R_{0}$ from the Rice and Tracey analysis [15].

Using a CT specimen, three different configurations (Fig. 1) have been analyzed:

(i) monometallic $(\mathrm{BM})$, where only the $\mathrm{BM}$ is considered;

(ii) bimetallic (BM+WM), where the HAZ is neglected;

(iii) trimetallic $(\mathrm{BM}+\mathrm{HAZ}+\mathrm{WM})$, where the complete joint is considered.

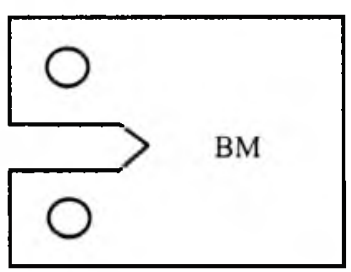

Monometallic

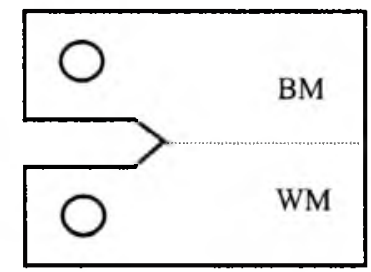

Bimetallic

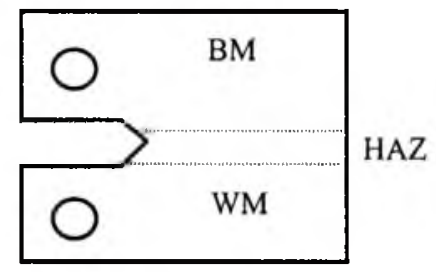

Trimetallic

Fig. 1. Three configurations of the CT25 specimen (schematic).

For each configuration, the $J$ and CTOD parameters, as well as the parameter $R / R_{0}$, are numerically determined. For the base metal, for which experimental data of ductile tearing are available, the crack growth is modeled using the Rice and Tracey model. Numerical results are then compared to experimental data.

1. Materials. The weld metal and the base metal are respectively $316 \mathrm{~L}$ and a Z3CN20-09M stainless steels. Their chemical composition is given in Table 1.

The mechanical behavior of each component (BM, WM, and HAZ) is described using the power law:

$$
\sigma=\sigma_{Y}+k \varepsilon_{p}^{n}
$$

where $\varepsilon_{p}$ is the plastic strain, $\sigma_{Y}$ is the yield stress, while $n$ and $k$ are the material constants.

The experimental values of $\sigma_{02}, n$, and $k$ obtained from experimental tensile tests performed at $673 \mathrm{~K}$ [17-18] are presented in Table 2. The elastic constants $E$ and $v$ are respectively $176 \cdot 10^{3} \mathrm{MPa}$ and 0.3 . 
$\mathrm{T}$ a b 1 e 1

Chemical Composition of Stainless Steels (\%wt.)

\begin{tabular}{|c|c|c|c|c|c|c|c|c|c|c|c|}
\hline Material & $\mathrm{C}$ & $\mathrm{S}$ & $\mathrm{P}$ & $\mathrm{Si}$ & $\mathrm{Mn}$ & $\mathrm{Ni}$ & $\mathrm{Cr}$ & $\mathrm{Mo}$ & $\mathrm{Cu}$ & $\mathrm{N}$ & $\mathrm{O}$ \\
\hline Base metal & 0.015 & 0.003 & 0.022 & 1.15 & 1.01 & 9.74 & 20.01 & 0.39 & 0.125 & 0.081 & 0.006 \\
\hline Weld metal & 0.008 & 0.011 & 0.018 & 0.51 & 1.19 & 12.70 & 19.20 & 2.60 & 0.137 & 0.051 & 0.007 \\
\hline
\end{tabular}

T a b 1 e 2

Values of the Yield Stress and the Parameters of the Power Law

\begin{tabular}{|c|c|c|c|}
\hline Characteristic & BM & HAZ & WM \\
\hline$k, \mathrm{MPa}$ & 1066.9 & 324.58 & 324.58 \\
\hline$n$ & 0.826 & 0.206 & 0.206 \\
\hline$\sigma_{02}, \mathrm{MPa}$ & 133 & 320 & 412 \\
\hline
\end{tabular}

2. Numerical Study. The modeled specimen is a standard CT specimen of $25 \mathrm{~mm}$ thickness, $50 \mathrm{~mm}$ width and with ratio $a / W=0.63$. The Systus FEM software has been used in this investigation. Large strains, plane strain situation, and isotropic hardening with a von Mises rule have been assumed in the calculations. The FEM modeling incorporates the eight-noded isoparametric element (six nodes for triangles) [14, 17-19].

As shown in Fig. 2, the meshing consists of a fine square mesh around the crack tip $(0.2 \times 0.2 \mathrm{~mm})$ and a relatively coarse mesh near the boundary. Because of symmetry, only half of the specimen was modeled, in the case of monometallic configuration. The typical discretization consisted of 1954 nodal points and 618 elements. Concerning the case of the heterogeneous material (bi- and trimetallic configurations), the whole specimen has to be analyzed. This meshing contains 1236 elements and 3857 nodes.

The crack is located in the HAZ, about $1 \mathrm{~mm}$ from the melting line (the width of the HAZ is taken equal to $3 \mathrm{~mm}$ ), while it was assigned at the interface for the bimetallic specimen. The specimen loading is applied, step by step, in terms of assigned displacement.

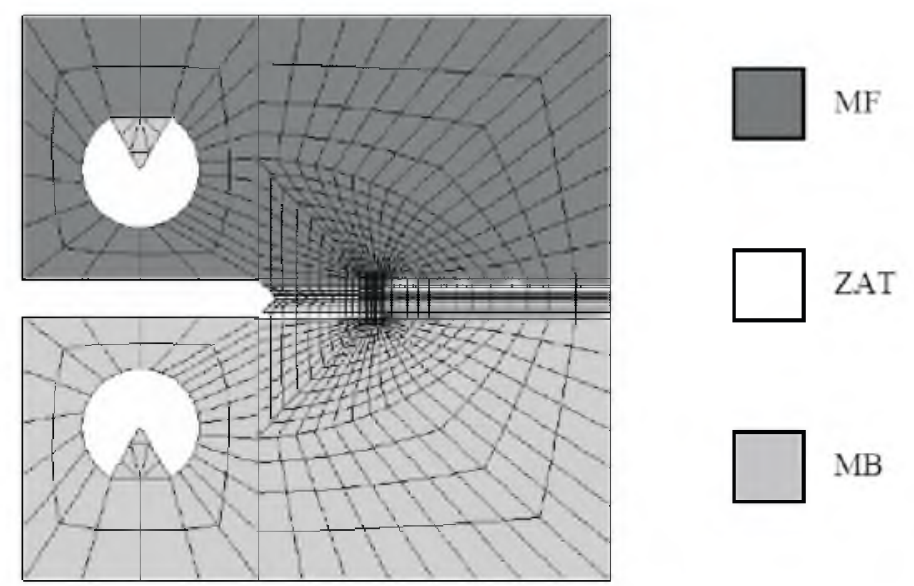

Fig. 2. FEM meshing of the CT specimen. 
3. Results and Discussions. Firstly we have obtained FEM results on global parameters (the applied load, $J$-integral, and CTOD) and the local parameter $R / R_{0}$ and then studied their evolution as function of the load line displacement.

In a second step, a FEM analysis of crack growth for the base metal, based upon a critical growth rate criterion has been performed and results were compared to the experimental data in terms of $J-\Delta a$ evolution.

3.1. Load-Displacement. For all the configurations, the evolution of the load per unit thickness as a function of the assigned displacement is shown in Fig. 3.

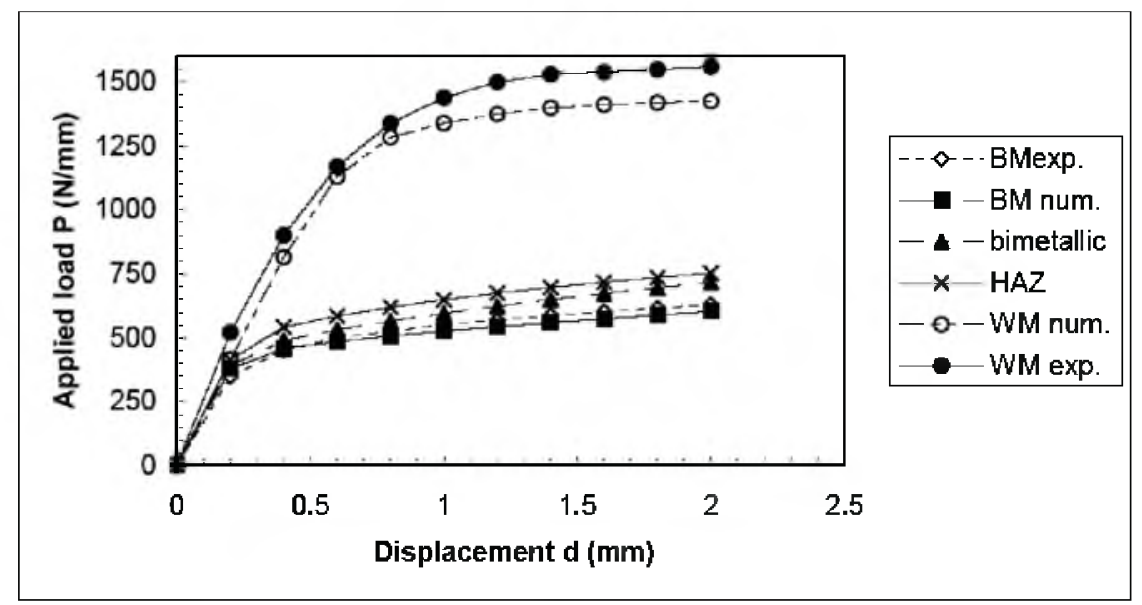

Fig. 3. Load as a function of the assigned displacement.

In the case of the base metal specimen, for which experimental results are available a good agreement is pointed out between experimental and numerical data, indicating that the hypothesis of computation are reasonable.

When comparing the bi- and trimetallic configurations, similar behavior is observed. For example, for a given displacement $(d=2 \mathrm{~mm})$, the relative difference between the corresponding loads does not exceed $5 \%$.

The relative difference between the bimetallic or trimetallic curves and the monometallic one is not high for BM (approximately 20\% for $d=2 \mathrm{~mm}$ ). However, it is more significant when considering the WM curve $(89 \%$ for the same displacement). The global behavior of the bi- and trimetallic configurations is assumed to be governed by the base metal because of its lower yield stress. Indeed, these configurations exhibit a generalized yielding in the base metal while the plastic zone in the WM is rather small. This observation is often shown in overmatching case (in our case, the overmatching ratio is equal to $M=3.1$ ).

3.2. Profile of the Crack Opening. In the case of the monometallic and the trimetallic specimen, Fig. 4 shows the crack lips opening versus the distance $X$ to the crack tip in a deformed state (here $d=2 \mathrm{~mm}$ ).

One of the most evident features is the typical dissymmetry of the profile when considering the trimetallic configuration. This is a consequence of the plastic zones around the crack which is more critical in the base metal. Indeed, in this case, the plasticity is confined in the HAZ at the beginning of the loading, but it develops quickly from the interface towards the BM in which a full-scale yielding process takes place because of its lower yield stress. 


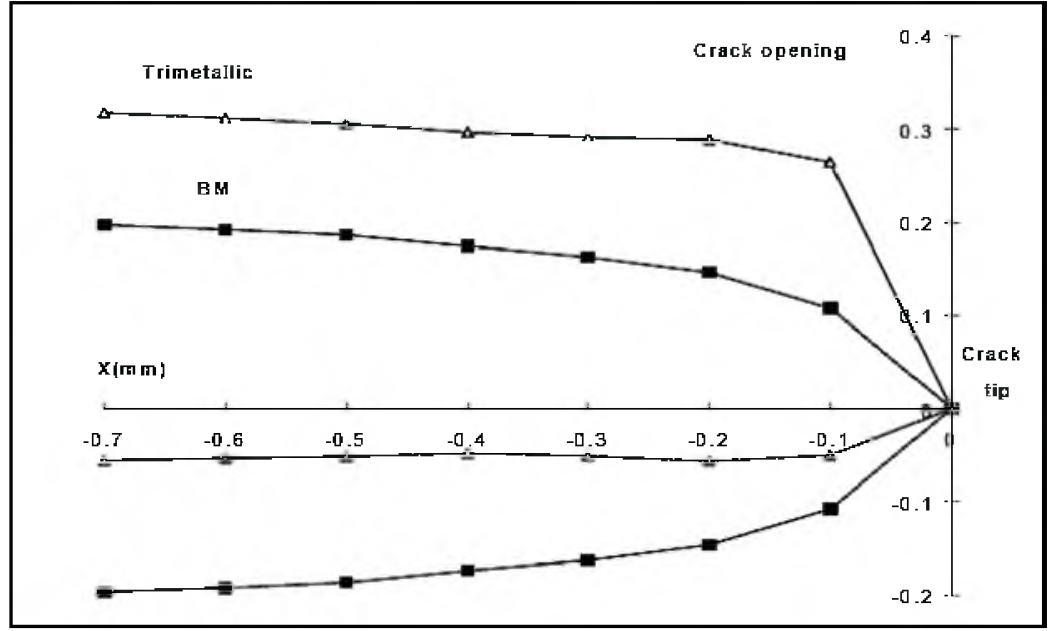

Fig. 4. Profile of the crack opening $(d=2 \mathrm{~mm})$

No significant plastic strain is observed in the WM zone. Thus, the plastic zone is mushroom-shaped, which is typical for lap welded joints.

In the case of the bimetallic specimen, the crack is located at the interface. The yielding occurs and develops essentially in the BM.

Furthermore, concerning the trimetallic configuration, the total CTOD $\left(\delta_{t o t}\right)$ can be divided into two components: the first one related to the base metal $\left(\delta_{B M}\right)$ and the second one related to the weld metal $\left(\delta_{W M}\right)$. As shown in Fig. 5, because of the mismatching level, the first component contributes about $85 \%$ of the total CTOD when the displacement is $2 \mathrm{~mm}$.

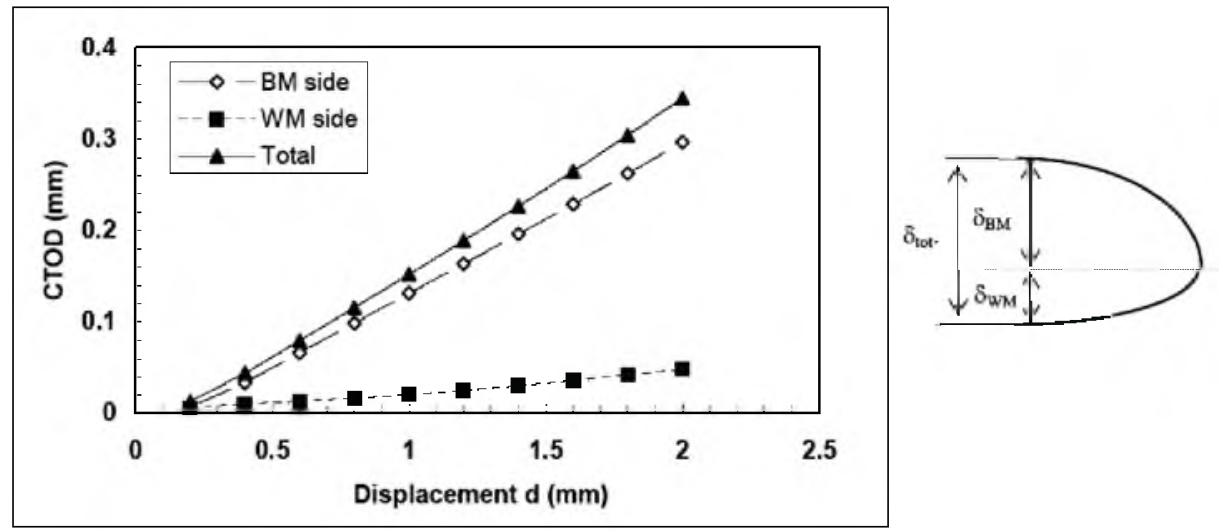

Fig. 5. $\delta_{\text {tot }}, \delta_{M B}$, and $\delta_{W M}$ versus the loading points displacement (trimetallic).

When plotting the total CTOD versus the displacement (Fig. 6), similar behaviour for the three configurations is observed. As it was already mentioned, the CTOD value is mostly governed by the base metal. This statement is in agreement with the results obtained by Toyoda [5] 


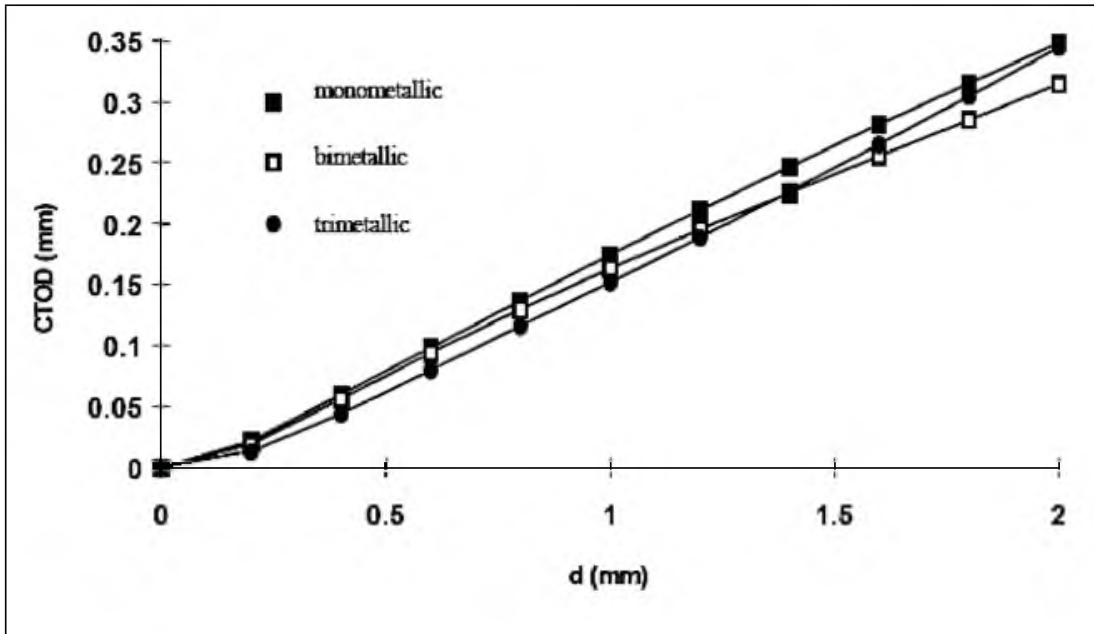

Fig. 6. CTOD vs displacement for the three configurations

3.3. The J-Integral Analysis. The J-integral has been calculated following a chosen path using the expression proposed by Rice [1]:

$$
J=\int_{\Gamma}\left[W(\varepsilon) d x_{2}-\vec{t} \frac{d \vec{u}}{d x_{1}} d s\right] .
$$

On an other hand, using the load-displacement numerical data, the energy parameter $J$ has been determined via the ASTM procedure [16]:

$$
J=\eta_{p} \frac{U_{p}}{B\left(W-a_{0}\right)}+\frac{K_{1}^{2}}{E^{\prime}},
$$

where $E^{\prime}=E /\left(1-v^{2}\right)$; for the CT specimen

$$
\eta_{p}=2+0.522\left(1-a_{0} / W\right)
$$

where $K_{1}$ is stress intensity factor, $a_{0}$ is the initial crack length, $W$ is the specimen width, $B$ is the specimen thickness, and $U_{p}$ is the plastic component of the area under load-displacement curve.

It is noted that, for each configuration, a good agreement between the $J$-integral and the energy parameter $J$ has been obtained. Indeed, the maximum difference between the results is less than $5 \%$.

A plot of the $J$-integral versus the loading points displacement is presented in Fig. 7. The results confirm our primary observations on the load-displacement curves. Again, a similar global behavior is observed, indicating that this parameter is not much affected by change in the specimen configuration.

Finally, for each configuration, a linear relationship between $J$ and CTOD is obtained as already observed in $[7,13]$. 


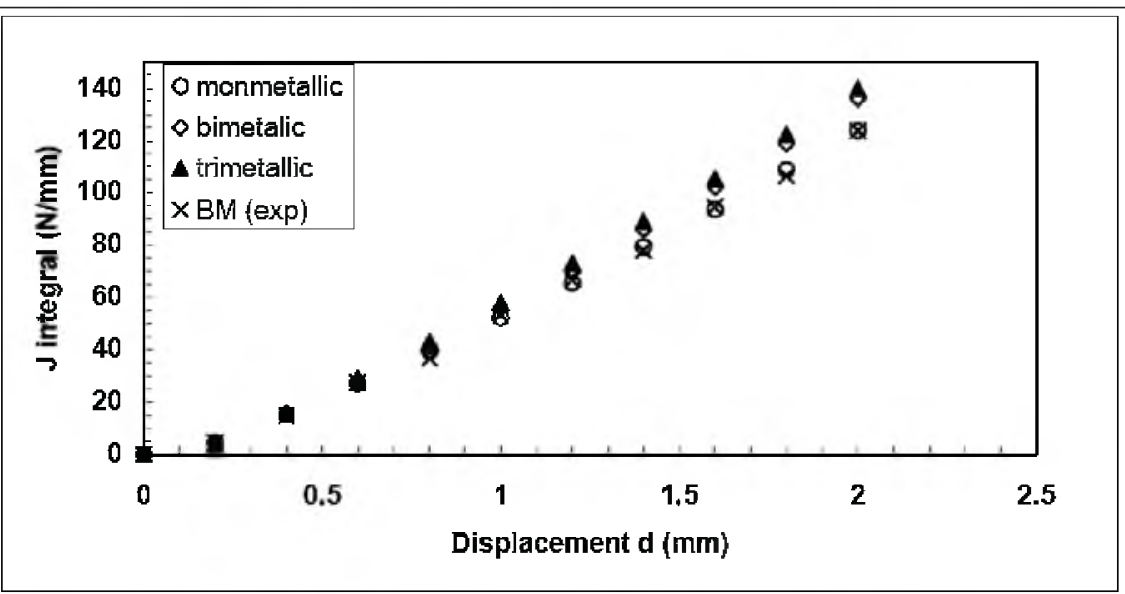

Fig. 7. J-integral versus displacement for the three configurations.

From the above-mentioned results either in terms of load-displacement, CTOD or $J$-integral, one may conclude that the global behavior of the welded joints in a lap joint situation, is mainly governed by the material which mechanical properties the worst. This raises the question about the validity of a global approach when dealing with a fracture of mismatched welded joints.

3.4. Void Growth Model. This kind of model is based upon the assumption that ductile failure is the consequence of void growth mechanisms which initiate from inclusions or particles contained in the material. Many models, giving the evolution of the defect size, have been proposed, e.g., $[14,15]$. More precisely, Rice and Tracey [15] expressed the void growth rate as

$$
d\left(\ln R / R_{0}\right)=0.283 \exp \left[1.5 \frac{\sigma_{m}}{\sigma_{e q}}\right] d \varepsilon_{e q},
$$

where $R_{0}$ is the initial radius of the void, $R$ is the current radius of the void, $\sigma_{m}$ is hydrostatic stress, $\sigma_{e q}$ is the equivalent von Mises stress, and $d \varepsilon_{e q}$ is increment of the equivalent plastic strain.

For a given element, the void growth parameter $R / R_{0}$ is computed, using the average values of stresses and strains $[14,19]$. Considering the trimetallic specimen, the values of this parameter are calculated in the element lying to the BM side since the BM exhibits the lowest yield stress [14, 17, 19]. Figure 8 shows the evolution of the void growth rate as function of the load line displacement for the three configurations.

In contradiction with the $J$-integral, the void growth parameter is very sensitive to the stress and strain distribution as confirmed by the significant difference observed in the evolution of $R / R_{0}$. As shown in Fig. 9, a plot of this parameter as a function of $J$ leads to a similar conclusion.

Considering these results, it must be emphasized that:

Because the crack is located at the interface, the bimetallic specimen exhibits higher values of $R / R_{0}$ than those obtained for the other configurations. Because the void growth parameter increases quickly, this case seems to be the most 
harmful. This is mainly a consequence of the yielding process which develops in the base metal only.

Figure 9 also illustrates the beneficial effects of the HAZ when considering the trimetallic specimen. In this case, data on $R / R_{0}$ constitute a lower limit because they are computed for the HAZ with the yield stress approximately twice as high as that of the BM.

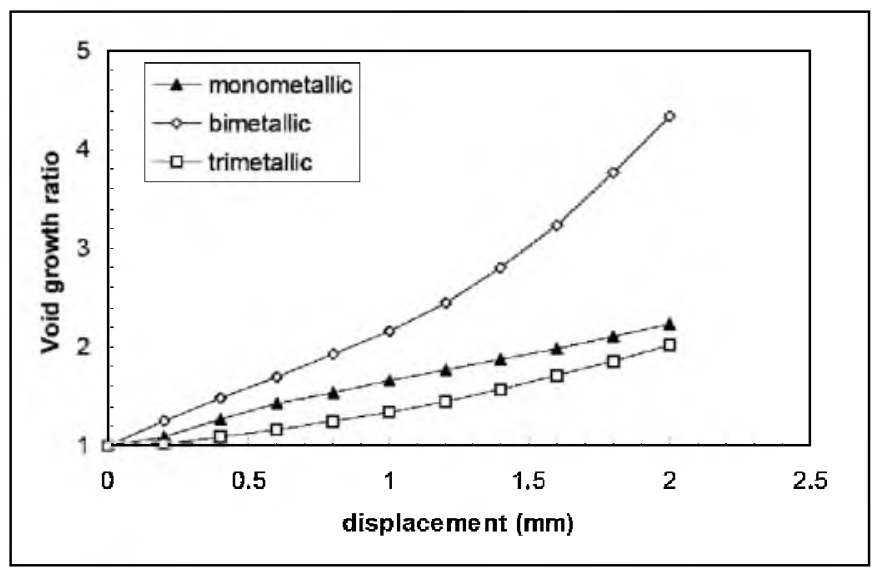

Fig. $8 . R / R_{0}$ vs displacement for the three configurations.

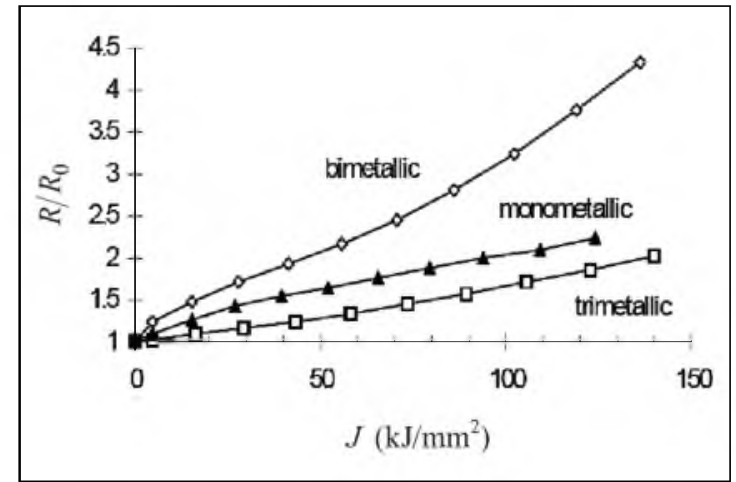

Fig. 9. $R / R_{0}$ vs $J$ for three configurations.

Therefore, adopting the softer material properties to characterize fracture of lap welded joints seems to be a conservative approach.

3.5. Crack Growth Modeling. The crack growth simulation is modeled using a critical void growth rate $\left(R / R_{0}\right)_{c}$ criterion value which is determined by combining experimental and FEM results in the BM case.

On one hand, according to experimental results of fracture test on a CT25 specimen, the critical load $P_{i}$, corresponding to the crack initiation, has been determined. Precisely, $P_{i}=600 \mathrm{~N} / \mathrm{mm}$, which corresponds to the point where the crack extension has reached $0.2 \mathrm{~mm}$ (Fig. 10).

On an other hand, the FEM analysis of the same specimen gives the evolution of the void growth ratio, determined in the first element in front of the crack tip, as a function of the applied load. According this curve, the $\left(R / R_{0}\right)_{c}$ value corresponds to $P_{i}$ value (see Fig. 11). 


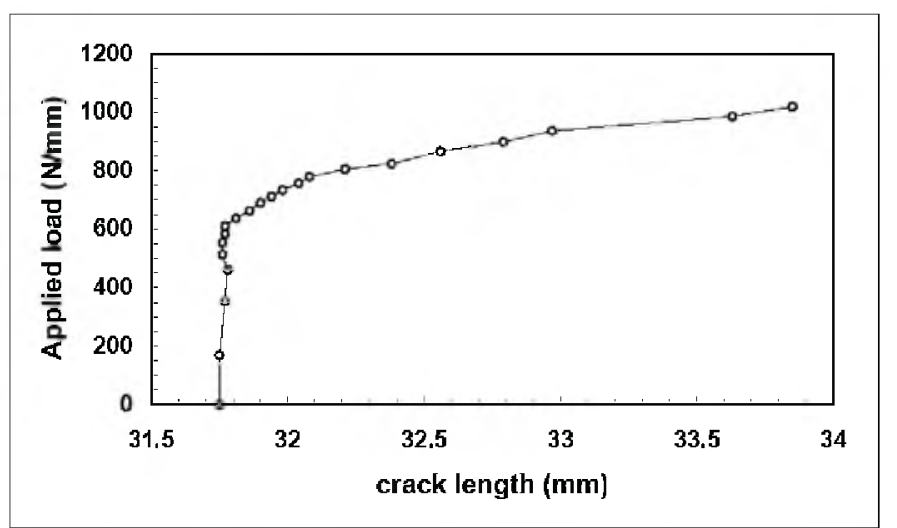

Fig. 10. Applied load vs crack length (BM case): experimental determination of the critical load value $P_{i}$.

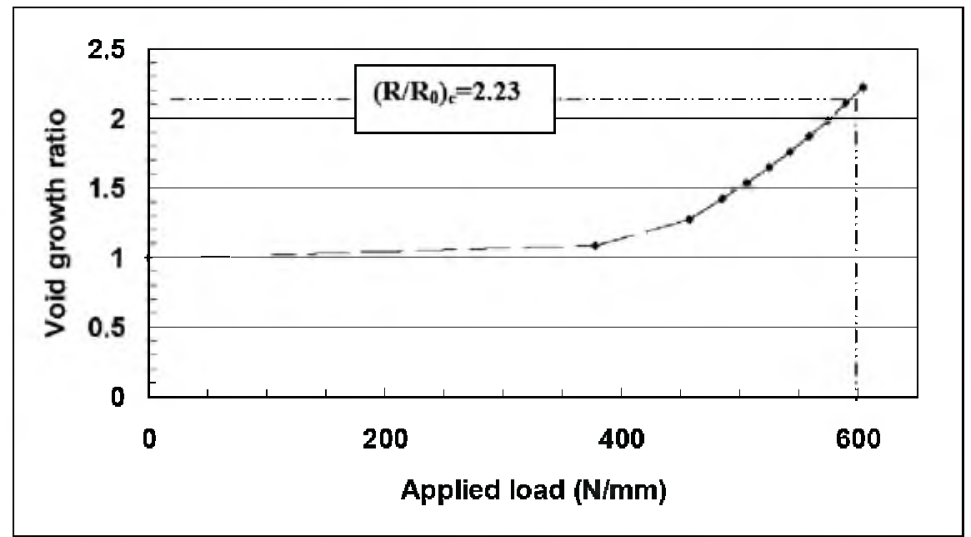

Fig. 11. Void growth ratio vs applied load (numerical results for BM case): critical void growth ratio determination.

For to enlarge the crack, the FEM analysis has been achieved using a node release technique which assumes the crack propagation direction is known [14, 19]. In our case, where only the monometallic configuration is considered, we assume that the crack propagates in the initial plane notch. The crack is increased by an amount $\Delta a=0.2 \mathrm{~mm}$ (corresponding to the element size around the crack tip) by releasing the nodes of the first element in front of the crack tip when $\left(R / R_{0}\right)_{c}$ is reached in this element. Increasing the load, the same operation is carried out again until reaching the crack propagation instability. Figure 12 shows the different steps used in the node release technique.

For each crack extension, the energy parameter $J$ is determined using the ASTM procedure [13] briefly developed above. A comparison of experimental and numerical results is given in Fig. 13, where $J$ is plotted versus crack extension $\Delta a$. Experimental and numerical estimation of the tearing rate $d J / d a$ are in good agreement but for a given numerical value of $J$ is clearly underestimated. This divergence may be the consequence of the following factors:

1). The degree of uncertainty on the critical value of the void growth parameter. 
2). The element size of the meshing, which plays an important role in the crack propagation simulation [19]. It seems that the values we have assigned here are high enough for the constant $J$, and therefore, the crack extension $\Delta a$ (which is equal to the element length) is overestimated.

3). The fact that the FEM analysis has been performed with the assumption that crack propagates in its initial plane. A deviation of the crack, which is often observed experimentally, involves an increase in the energy parameter $J$. This may be also an explanation for the numerical underestimation of this parameter.

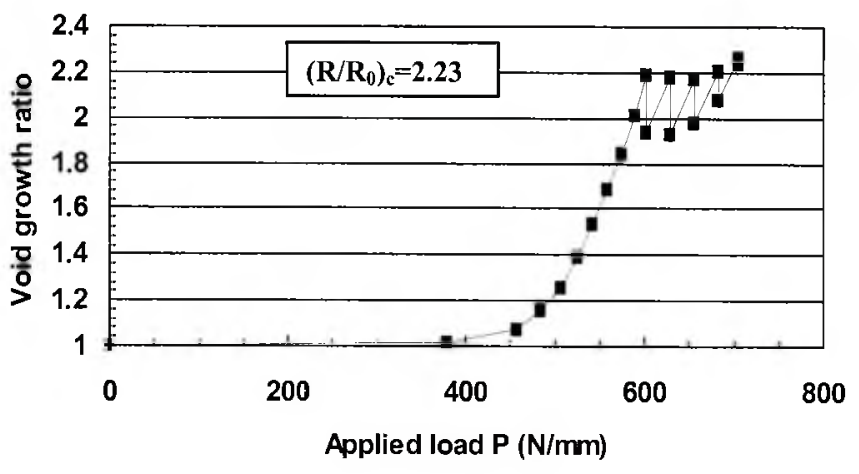

Fig. 12. Void growth ratio vs applied load: the node release technique.

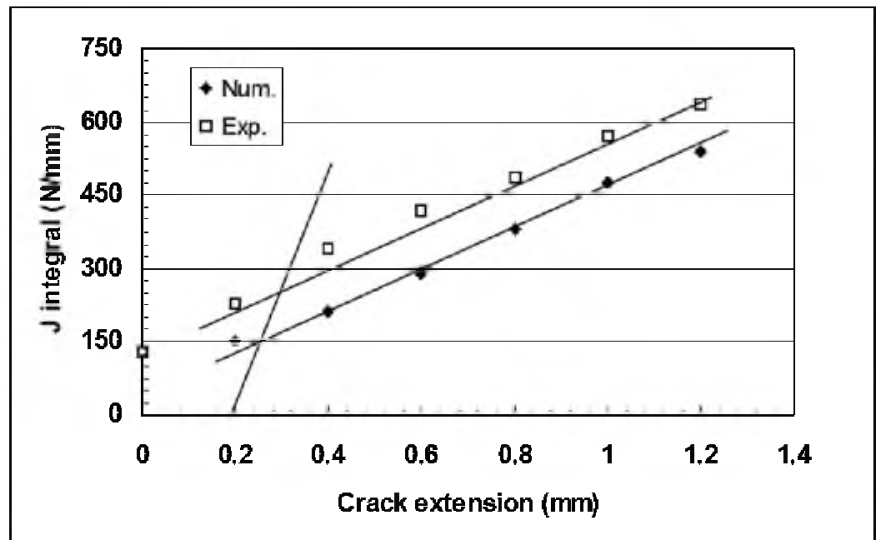

Fig. 13. Energy parameter $J$ vs crack extension (BM case): comparison between experimental and numerical results.

Conclusions. The main results of this study may be summarised as follows:

1. In terms of load-displacement curves, when considering the BM configuration, numerical data are in good agreement with experimental values, confirming the validity of the numerical modeling (meshing, material behaviour, boundary conditions, etc).

2. Concerning the bi- and trimetallic specimens, a similar evolution of their global behavior has been observed in terms of load-displacement response, as well as in terms of $J$-integral or CTOD results.

3. Concerning the trimetallic specimen, a linear dependence of the CTOD parameter upon the $J$-integral has been observed. It is noteworthy that the BM 
provides a major contribution to the total CTOD value, because of its lower mechanical strength.

4. The different cases lead to a globally similar evolution of CTOD, when plotted versus the $J$-integral, indicating that these two parameters are not really affected by a change in the specimen configuration.

5 . The evolution of the void growth rate parameter $R / R_{0}$ is significantly different since it is very sensitive to the local stress and strain fields and can be used for prediction of both crack initiation and crack propagation. Therefore, this parameter (and more generally, the local approach) can be applied as an alternative and/or complementary tool for the fracture analysis of mismatched welded joints.

Acknowledgement. This research was supported by the Mechanics and Technology Department, Les Renardiêres Research Center, Electricité de France (EDF).

\section{Резюме}

Виконано числовий розрахунок параметрів в'язкого руйнування компактних зразків, що моделюють зварне з'єднання внапуск. Досліджували моно-, бі- та триметалічні конфігурації компактних зразків із метою порівняння глобальних ( -інтеграл та розкриття вістря тріщини) і локального (модель Райса-Трейсі) підходів. Показано, що такі зміни конфігурації зразків не впливають на глобальні параметри, в той час як локальний параметр коефіцієнт росту пор $R / R_{0}$ - дуже чутливий до зміни полів напружень $\mathrm{i}$ деформацій в околі вістря тріщини. Пропонується напрямок поширення тріщини у випадку зварного з'єднання внапуск прогнозувати по розподілу параметра $R / R_{0}$ в околі вістря тріщини.

1. J. Rice, "Mathematical analysis in the mechanics of fracture," in: H. Liebowitz (Ed.), Fracture, Academic Press (1968), Vol. 2, pp. 191-311.

2. Y. Lai and R. A Ainsworth, "A $J$-integral estimation method for cracks in welds mismatched mechanical properties," Int. J. Pres. Ves. Piping, 70, 237-345 (1997).

3. K.-H. Schwalbe, "Effect of weld metal mismatch on toughness requirements: Some simple analytical considerations using the engineering treatment model (ETM)," Int. J. Fract., 56, 257-277 (1992).

4. R. Denys, "Strength and performance characteristics of welded joints," in: K.-H. Schwalbe and M. Koçac (Eds.), Mis-Matching of Welds (ESIS 17), Mechanical Engineering Publications, London (1994), pp. 59-102.

5. M. Toyoda and K. Satoh, "Ténacité à la rupture des soudures: influence d'une hétérogénéité mécanique sur la corrélation des paramêtres de ténacité," Soudage et Techniques Connexes, Nov.-Déc., 398-407 (1985).

6. C. Eripret, S. Ignaccolo, and P. Gilles, "Study of mechanical behavior and fracture resistance of welded joints," Rev. Métal., Fév., 214-225 (1995). 
7. J. Joch and R. A. Ainsworth, "Relationships between the $J$-integral and the crack tip opening displacement for stationary cracks in weldments at plastic collapse," Fatigue Fract. Eng. Mater. Struct., 17, No. 10, 1175-1185 (1994).

8. J. D. G. Sumpter, " $J_{c}$ determination for shallow notch welded bend specimens," Fatigue Fract. Eng. Mater. Struct., 10, No. 6, 479-493 (1987).

9. M. Toyoda, F. Minami, C. Ruggieri, et al., "Fracture property of HAZ-notched weld joint with mechanical," in: K.-H. Schwalbe and M. Koçac (Eds.), Mis-Matching of Welds (ESIS 17), Mechanical Engineering Publications, London (1994), pp. 399-415.

10. W. Burget and J. G. Blauel, "Fracture toughness of welding procedure qualification and component welds tested in SENB- and C-specimens," in: J. G. Blauel and K.-H. Schwable (Eds.), The Fracture Mechanics of Welds (EGF), Mechanical Engineering Publications, London (1987), pp. 19-42.

11. J. Joch, R. A. Ainsworth, and T. H. Hyde, "Limit load and $J$-estimates for idealised problems of deeply cracked welded joints in plane-strain bending and tension," Fatigue Fract. Eng. Mater. Struct., 16, No. 10, 1061-1079 (1993).

12. A. Heuser, R. Twickler, and W. Wahl, "Experimental investigations of the failure behaviour of welded joints and its numerical simulation by using elastic-plastic finite element calculations," in: J. G. Blauel and K.-H. Schwable (Eds.), The Fracture Mechanics of Welds (EGF), Mechanical Engineering Publications, London (1987), pp. 97-124.

13. A. Al Rassis, Contribution à la Déchirure Ductile à Chaud Dans les Joints Soudés et Modélisation Numérique en Approche Globale et en Approche Locale, Thèse de Doctorat, Université de Lille I, (1995).

14. J. R. Rice and D. M. Tracey, "On the ductile of voids in triaxial stress fields," J. Mech. Phys. Solids, 17, 201-217 (1969).

15. G. Rousselier, "Les modèles de rupture ductile et leurs possibilités actuelles dans le cadre de l'approche locale de la rupture," in: Int. Seminar on Local Approach of Fracture, Moret-Sur-Loing, France (1986), pp. 257-284.

16. ASTM Standard E 813-89, Standard Test of $J_{1 c}$, a Measure of Fracture Toughness (1989).

17. P. Gilles and C. Franco, "A new $J$-estimation scheme for cracks in mismatching welds - the ARAMIS method," in: K.-H. Schwalbe and M. Koçac (Eds.), Mis-Matchnig of Welds (ESIS 17), Mechanical Engineering Publications, London (1994), pp. 661-683.

18. C. Eripret and P. Hornet, "Prediction of overmatching effects on the fracture of stainless steel cracked welds," in: K.-H. Schwalbe and M. Koçac (Eds.), Mis-Matchnig of Welds (ESIS 17), Mechanical Engineering Publications, London (1994), pp. 685-708.

19. J. Wilsius, A. Imad, M. Nait Abdelaziz, et al., "Void growth and damage models for predicting ductile in welds," Fatigue Fract. Eng. Mater. Struct., 23, 105-112 (2000). 